\title{
Synthesis of amphiphilic sulfonamide halogenated porphyrins: MALDI-TOFMS characterization and evaluation of 1-octanol/water partition coefficients
}

\author{
Carlos J.P. Monteiro ${ }^{a}$, Mariette M. Pereira ${ }^{a}, *$, Sara M.A. Pinto ${ }^{a}$, Ana V.C. Simões ${ }^{a}$, Gonçalo F.F. Sáa \\ Luís G. Arnaut ${ }^{a}$, Sebastião J. Formosinho ${ }^{a}$, Sérgio Simões ${ }^{b}$, Mark F. Wyatt ${ }^{c}$ \\ a Departamento de Química, Universidade de Coimbra, Rua Larga, 3004-535 Coimbra, Portugal \\ ${ }^{\mathrm{b}}$ Bluepharma SA, São Martinho do Bispo, 3045-016 Coimbra, Portugal \\ ${ }^{\mathrm{C}}$ EPSRC National Mass Spectrometry Service Centre (NMSSC), School of Medicine, Swansea University, Singleton Park, Swansea SA2 8PP, UK
}

\section{A R T I C L E I N F O}

\section{Article history:}

Received 8 February 2008

Received in revised form 13 March 2008

Accepted 17 March 2008

Available online 21 March 2008

\section{Keywords:}

Amphiphilic porphyrins synthesis

1-Octanol/water partition coefficients MALDI-TOFMS

\begin{abstract}
A B S T R A C T
Porphyrins are key precursors for development of photosensitizers for photodynamic therapy. A new series of ortho-halogenated tetraarylporphyrins with sulfonamide substituents have been synthesized via chlorosulfonation reaction and characterized by MALDI-TOFMS. To predict their partition properties, $\log K_{\mathrm{OW}}$ of a selected range of the synthesized halogenated amphiphilic porphyrins is described. A significant effect of the number and type of halogen group as well as on the number of sulfonamide side chain was observed. The determined 1-octanol/water partition coefficients showed that it is possible to obtain compounds with a wide range of lipophilicities, from $\log K_{\mathrm{OW}}=-2.71$ till $\log K_{\mathrm{OW}}>4$, which are suitable to optimize the biological efficacy of this class of sensitizers.
\end{abstract}

(c) 2008 Elsevier Ltd. All rights reserved.

\section{Introduction}

Tetrapyrrolic macrocyles namely porphyrins ${ }^{1,2}$ and their reduced derivatives, chlorins ${ }^{3,4}$ and bacteriochlorins, ${ }^{5,6}$ have been described as selective model sensitizers for photodynamic therapy (PDT).$^{7-10}$ We have shown that the singlet-triplet intersystem crossing, and the consequent increase in singlet oxygen quantum yield, can be improved in this class of sensitizers with the introduction of halogen atoms in their structure. ${ }^{2,11}$ The performance of the halogenated sensitizers in vitro was recently assessed and met with the expectation of improved photodynamic activity. ${ }^{12}$ Further progress can be expected from the introduction of amphiphilic properties in halogenated porphyrins, which will combine high singlet-triplet intersystem crossings with enhanced lipid bioavailability. ${ }^{13-16}$ Additionally, such porphyrins are synthetic precursors of other sensitizers, such as chlorins and bacteriochlorins, ${ }^{17}$ which have strong absorptions at longer wavelengths.

The synthesis of meso-aryl halogenated porphyrins may follow two basically different methodologies: the Lindsey two-step approach $^{18-20}$ or the Gonsalves and Pereira nitrobenzene one-pot method. ${ }^{21,22}$ In the first method, the step of the condensation of pyrrole with the desired halogenated aldehyde to yield the porphyrinogen is separated from the second step of the oxidation of

\footnotetext{
* Corresponding author. Tel.: +351 239854 474; fax: +351 239827703.

E-mail address: mmpereira@qui.uc.pt (M.M. Pereira).
}

the porphyrinogen to the corresponding porphyrins, using dichlorodicyanoquinone (DDQ) or tetrachloro-1,4-benzoquinone (chloranil) as oxidant. In the second approach, a simple mixture of pyrrole and the aldehyde using organic acid and nitrobenzene in an aerated solution and high temperatures gives, directly from the reaction medium, the corresponding porphyrins. The Lindsey approach gives high yields but large dilutions and expensive quinones are required, which make the method quite expensive. On the other hand, the nitrobenzene approach gives low yields with 5,10,15,20tetrakis(2,6-dichlorophenyl)porphyrin (TDCPP), but high concentrations can be used and pure porphyrins crystallize directly from the reaction medium. In view of the economical advantages and of the possibility of obtaining pure porphyrins, the second synthetic method was selected for this study.

According to the literature, the aromatic electrophilic chlorosulfonation of porphyrins and corroles using chlorosulfonic acid is an attractive method to obtain the corresponding chlorosulfonic derivatives with high yields and purity. The chlorosulfonations of 5,10,15,20-tetrakisphenylporphyrin (TPP), 5,10,15,20-tetrakis(2-chlorophenyl)porphyrin (TCPP) and TDCPP proceed with excellent selectivity for the phenyl ring, as opposed to the selective substitution of $\beta$-pyrrole $\mathrm{H}$ atoms in corroles ${ }^{23,24}$ yielding the stable tetra-chlorosulfonated porphyrinic compounds with high yields. $^{12,25,26}$ These chlorosulfonates revealed also excellent reactivities towards nucleophiles like water, amines, alcohols or amino acids. ${ }^{12,23-28}$ Metallocomplexes of amphiphilic sulfonamide porphyrins proved to be quite good catalysts for epoxidation of 
alkenes $^{29}$ and oxidation of azo dyes in biphasic systems using hydrogen peroxide as oxidant. ${ }^{30}$ Furthermore, the synthesis of amphiphilic corroles with sulfonic acid head groups and their multiple applications on bio-mimetic catalysis, ${ }^{31,32}$ bio-medicine ${ }^{33,34}$ and photovoltaic cells ${ }^{35}$ have been recently described by Gross.

This study presents the synthesis of a large set of amphiphilic sulfonamide porphyrins, their characterization by matrix-assisted laser desorption/ionization time-of-flight mass spectrometry (MALDI-TOFMS), and the evaluation of their polarity in terms of 1-octanol/water partition coefficients $\left(K_{\mathrm{OW}} \mathrm{S}\right)$. As will be shown below, MALDI-TOFMS is particularly well suited for the analysis of these porphyrins because the only species observed is the $\mathrm{M}^{+\cdot}$ ion. The measurement of $K_{\mathrm{OW}} \mathrm{S}$ is motivated by the importance of this hydrophilicity/lipophilicity index in Medicinal chemistry. Our portfolio of sensitizers contains a large diversity of $K_{\mathrm{OW}} \mathrm{S}$ and is particularly well suited to rationalize subsequent studies on the properties of transport and biodistribution of tetrapyrrolic macrocycles as sensitizers in PDT.

\section{Results and discussion}

\subsection{Sulfonamide synthesis}

The 5,10,15,20-tetrakis(2-chlorophenyl)porphyrin 1, 5,10,15,20tetrakis(2,6-dichlorophenyl)porphyrin 2 and 5,10,15,20-tetrakis(2fluorophenyl)porphyrin $\mathbf{3}$ were prepared by one-pot condensation of pyrrole with the desired ortho-halogenated benzaldehyde using acetic acid/nitrobenzene as solvent and oxidant, accordingly to our previously described methodology. ${ }^{21,22}$ Using this synthetic approach, crystals of pure halogenated porphyrins $\mathbf{1}$ and $\mathbf{2}$ were obtained by direct crystallization from the reaction medium, in 4.5 and $9 \%$ isolated yields, respectively, which are in good agreement with literature. ${ }^{21,22}$ To the best of our knowledge, this is the first time that porphyrin 3 is described by this method, and a $20 \%$ yield of pure crystals was obtained.
In order to synthesize the desired halogenated amphiphilic porphyrins, the derivatization of $\mathbf{1 , 2}$ and $\mathbf{3}$ into the corresponding chlorosulfonated porphyrins was achieved by mixing the porphyrins with an excess of chlorosulfonic acid by optimization of temperatures and reaction times. Reaction of $\mathbf{1}$ with chlorosulfonic acid at $50{ }^{\circ} \mathrm{C}$ for $1 \mathrm{~h}$ affords the green tetra-substituted chlorosulfonyl derivative 5,10,15,20-tetrakis(2-chloro-5-chlorosulfophenyl)porphyrin 4. After cooling to room temperature, dichloromethane is added and the excess of acid is continuously extracted with water. After work-up, we obtained $94 \%$ of 4 . Due to the strong deactivation effect of two chlorine atoms, the chlorosulfonation of porphyrin 2 was carried out at $100{ }^{\circ} \mathrm{C}$ during $3 \mathrm{~h}$. After similar work-up, we obtained $92 \%$ of the 5,10,15,20-tetrakis(2,6-dichloro-3-chlorosulfophenyl)porphyrin $\mathbf{5}$. Porphyrin $\mathbf{3}$ was chlorosulfonated at $60{ }^{\circ} \mathrm{C}$ for $1.5 \mathrm{~h}$, yielding $97 \%$ of the 5,10,15,20-tetrakis(2-fluoro-5chlorosulfophenyl)porphyrin 6.

In spite of the remarkable stability of the chlorosulfonyl functionality towards hydrolysis and chromatographic conditions, these groups are susceptible to reaction with amines. ${ }^{23,25-30}$ Thus, adding an excess of the desired amine to a dichloromethane solution of the chlorosulfonated porphyrin derivatives 4,5 and 6 , and maintaining the reaction at room temperature for $3 \mathrm{~h}$, yields the corresponding sulfonamides (4a-e; 5a-e; 6a-e, see Scheme 1). After work-up, we isolated our portfolio of amphiphilic sulfonamide porphyrin derivatives with yields up to $75 \%$ (see Table 1 ).

In addition, the chlorosulfonated porphyrins $\mathbf{4 , 5}$ and 6 were suspended in water and maintained under reflux temperature for $12 \mathrm{~h}$ (see Scheme 1), yielding quantitatively the corresponding sulfonic acid porphyrins derivatives $\mathbf{4 f}, \mathbf{5 f}$, and $\mathbf{6 f}$ (see Table 1 ).

\subsection{Characterization of porphyrins by MALDI-TOFMS}

The new porphyrin derivatives presented in Table 1 were characterized by the methods described in Section 4, and in particular by MALDI-TOFMS. Acidic matrices were initially employed

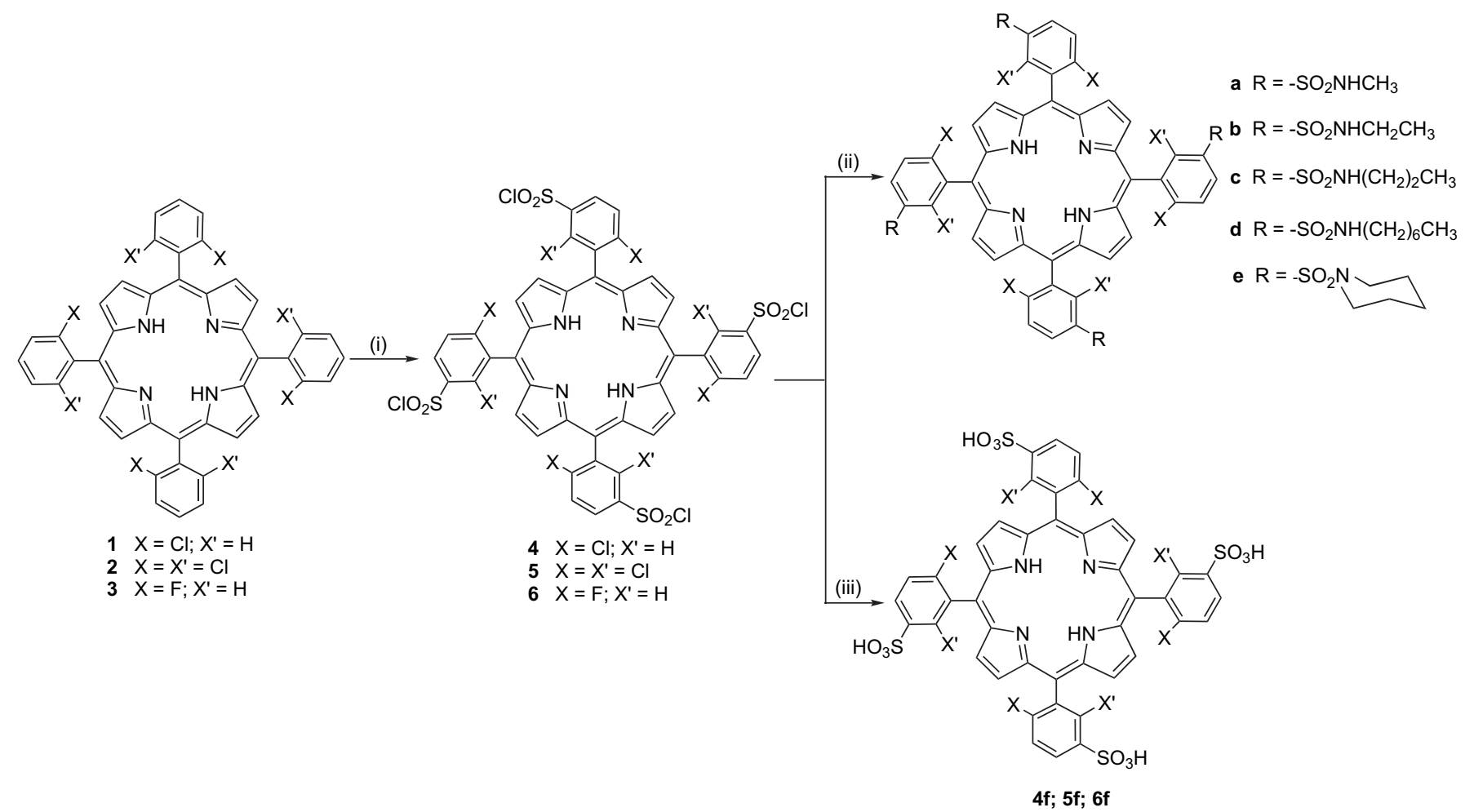

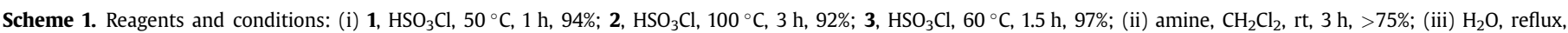
12 h, $100 \%$. 
Table 1

Yields of sulfonamide and sulfonic acid porphyrin derivatives (4a-f; $5 \mathbf{a}-\mathbf{f} ; \mathbf{6 a}-\mathbf{f}$ )

\begin{tabular}{lllllll}
\hline Nucleophile & $\begin{array}{l}\text { TCPPSO } \\
\text { derivatives }\end{array}$ & $\begin{array}{l}\text { Yield } \\
(\%)\end{array}$ & $\begin{array}{l}\text { TDCPPSO } \\
\text { derivatives }\end{array}$ & $\begin{array}{l}\text { Yield } \\
(\%)\end{array}$ & $\begin{array}{l}\mathrm{TFPPSO}_{2} \mathrm{Cl}(\mathbf{6}) \\
\text { derivatives }\end{array}$ & $\begin{array}{l}\text { Yield } \\
(\%)\end{array}$ \\
\hline $\mathrm{NH}_{2} \mathrm{CH}_{3}$ & $\mathbf{4 a}$ & 75 & $\mathbf{5 a}$ & 94 & $\mathbf{6 a}$ & 78 \\
$\mathrm{NH}_{2} \mathrm{CH}_{2} \mathrm{CH}_{3}$ & $\mathbf{4 b}$ & 92 & $\mathbf{5 b}$ & 96 & $\mathbf{6 b}$ & 85 \\
$\mathrm{NH}_{2}\left(\mathrm{CH}_{2}\right)_{2} \mathrm{CH}_{3}$ & $\mathbf{4 c}$ & 78 & $\mathbf{5 c}$ & 89 & $\mathbf{6 c}$ & 82 \\
$\mathrm{NH}_{2}\left(\mathrm{CH}_{2}\right)_{6} \mathrm{CH}_{3}$ & $\mathbf{4 d}$ & 89 & $\mathbf{5 d}$ & 84 & $\mathbf{6 d}$ & 81 \\
$\left.\mathrm{NH}^{(} \mathrm{CH}_{2}\right)_{5}$ & $\mathbf{4 e}$ & 83 & $\mathbf{5 e}$ & 95 & $\mathbf{6 e}$ & 82 \\
$\mathrm{H}_{2} \mathrm{O}$ & $\mathbf{4 f}$ & 100 & $\mathbf{5 f}$ & 100 & $\mathbf{6 f}$ & 100 \\
\end{tabular}

for the analysis of porphyrins by MALDI-TOFMS in the mid-nineties, but positive radical ions $\left(\mathrm{M}^{+*}\right)$ were observed instead of the expected $[\mathrm{M}+\mathrm{H}]^{+}$species. $^{36}$ In general, the relative ionization energies of porphyrin and matrix facilitate the charge-transfer ionization mechanism. More recently, the charge-transfer matrix 2-[(2E)-3-(4-tert-butylphenyl)-2-methylprop-2-enylidene]malononitrile (DCTB) has been shown to be very effective for the analysis of porphyrins. ${ }^{37}$ MALDI-TOFMS spectra for $\mathbf{6 e}$ and $\mathbf{5 c}$ are given in Figure 1 . The spectra are easy to interpret because the only species observed is the $\mathrm{M}^{+\cdot}$ ion, with no aggregates, fragments or structurally similar by-products from the synthesis. The isotope pattern comparison lends further credence to the identification of the target compound, as opposed to another compound of isobaric nominal mass, especially for $\mathbf{5 c}$, with the very distinctive pattern arising from the eight chlorine atoms. However, MALDI-TOFMS characterization of $\mathbf{6 f}$ was not as straight forward, as no ions were observed when DCTB was used. With 2,5-dihydroxybenzoic acid (DHB) matrix, the $[\mathrm{M}+\mathrm{H}]^{+}$species was observed strongly, while there was no evidence for the $\mathrm{M}^{+\bullet}$ species (see Fig. 2). In addition, the $[\mathrm{M}+\mathrm{Na}]^{+}$and $[\mathrm{M}+\mathrm{K}]^{+}$species were observed, the cations being provided by ubiquitous trace impurities from solvents. Low intensity ions at slightly higher masses are artefacts of the MALDITOFMS analysis, corresponding to the $[\mathrm{M}-\mathrm{H}+2 \mathrm{Na}]^{+}$and $[\mathrm{M}-\mathrm{H}+\mathrm{Na}+\mathrm{K}]^{+}$species arising from replacement of acidic protons by metal cations. These data highlights the effect that peripheral functional groups (sulfonic acid in this case) have not only on the solubility of the porphyrin, but on the successful mode of ionization, and therefore planning of experimental conditions for
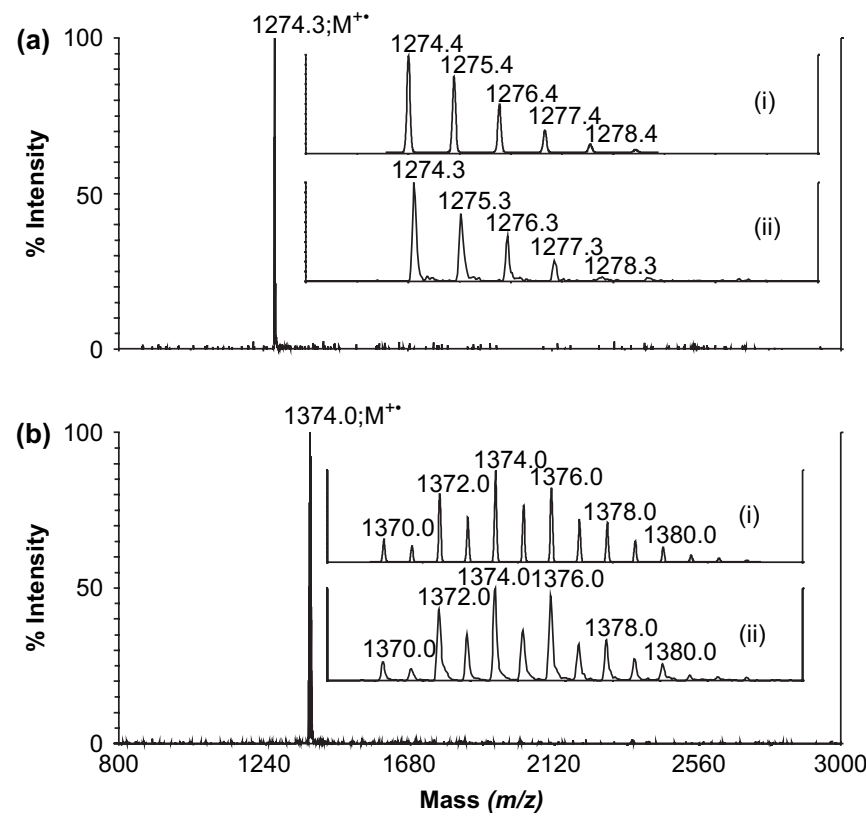

Figure 1. MALDI-TOFMS spectra for (a) $\mathbf{6 e}$ and (b) $\mathbf{5 c}$, acquired with DCTB. Inset shows comparison of theoretical (i) and observed (ii) isotope patterns.

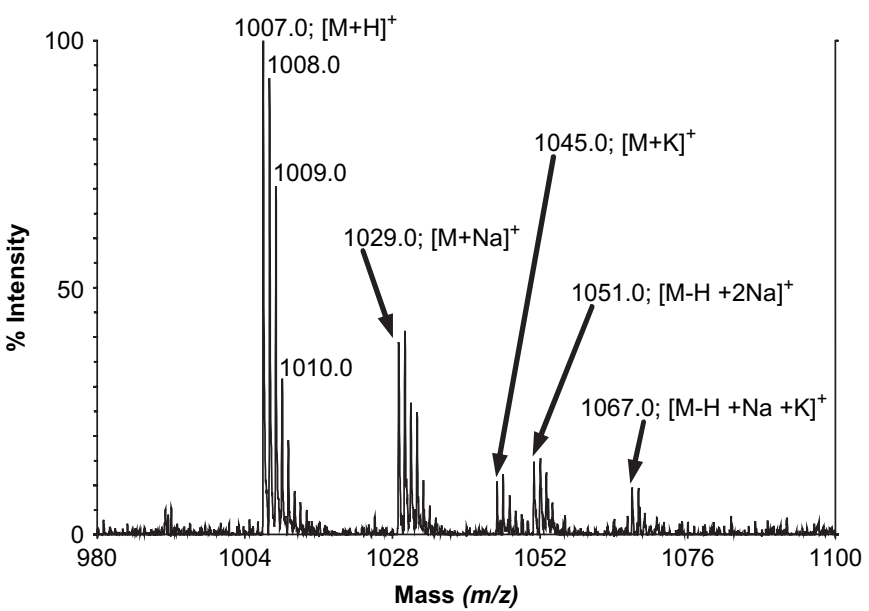

Figure 2. MALDI-TOFMS data for $\mathbf{6 f}$, acquired with DHB.

characterization by MALDI-TOFMS. The molecular ions $\mathrm{M}^{+\cdot}$ of all the sulfonamides are presented in Section 4.

\subsection{1-Octanol/water partition coefficients}

We evaluated the effect of the halogen atom and of the size of carbon sulfonamide chain on the 1-octanol/water partition coefficients of the porphyrins using a minor modification of the shake-flask method. ${ }^{38-40}$ The desired sulfonamide porphyrin was dissolved in 1-octanol saturated with phosphate buffer (PBS). This solution was then added to a PBS solution saturated with 1-octanol. The mixture of the two solvents was vigorously stirred, centrifuged and the solvents were separated. An appropriate volume of each phase was taken and diluted with ethanol. The fluorescence of each ethanol/1-octanol and ethanol/PBS solutions was measured, and compared with a calibration curve to obtain the concentration of the photosensitizer. The solutions for the calibration curves were either ethanol/1-octanol or ethanol/PBS, with precisely weighted amounts of the appropriate photosensitizer. The absorption band ca. $420 \mathrm{~nm}$ was excited, and the fluorescence was collected in the red region, under the same instrumental conditions for both the calibration curve and the samples. With this method we were able to obtain calibration curves for ethanol/PBS down to porphyrin concentrations of $10^{-7} \mathrm{M}$. The experiments with compounds $\mathbf{4 f}, \mathbf{5 f}$ and $\mathbf{6 f}$ were done in a similar way, but the sensitizers have been firstly dissolved in PBS solution saturated with 1-octanol. The partition coefficients were calculated according to the ratio $C_{\text {oct }} /$ $C_{\mathrm{PBS}}$, where $C_{\mathrm{oct}}$ and $C_{\mathrm{PBS}}$ are the concentrations of the sulfonamide porphyrin in the 1-octanol and in the PBS, respectively, and are presented in Table 2 .

Table 2

Partition coefficients $\left(\log K_{\mathrm{OW}}\right)$ in 1-octanol/water of selected sulfonamide and sulfonic acid porphyrin derivatives

\begin{tabular}{lc}
\hline Sulfonamide derivatives & $\log K_{\mathrm{OW}}$ \\
\hline $\mathbf{4 b}$ & $2.23 \pm 0.05$ \\
$\mathbf{4 f}$ & $-2.71 \pm 0.31$ \\
$\mathbf{5 b}$ & $1.84 \pm 0.12$ \\
$\mathbf{5 f}$ & $-1.80 \pm 0.38$ \\
$\mathbf{6 a}$ & $2.33 \pm 0.29$ \\
$\mathbf{6 b}$ & $2.53 \pm 0.08$ \\
$\mathbf{6 c}$ & $2.43 \pm 0.21$ \\
$\mathbf{6 d}$ & $>4^{\mathrm{a}}$ \\
$\mathbf{6 e}$ & $>4^{\mathrm{a}}$ \\
$\mathbf{6 f}$ & $-2.49 \pm 0.33$ \\
\hline
\end{tabular}


The values of $\log K_{\mathrm{OW}}$ determined for halogenated sulfonamide porphyrins show that it is possible to obtain a range of very hydrophilic to very hydrophobic compounds. The $\log K_{\mathrm{OW}}$ of these sensitizers depends on the number and type of halogen substituents. It decreases with the number of chlorine atoms in the ortho-position of the phenyl ring $(\mathbf{4 b}, \mathbf{5 b})$, and increases with the replacement of the chlorine atom by the less polarizable fluorine atom $(\mathbf{4 b}, \mathbf{6 b})$. As a result, the most lipophilic halogenated-ethylsulfamoylphenyl porphyrin is $\mathbf{6 b}$. The lipophilicity of fluorinated-alkylsulfamoylphenyl porphyrins can be further enhanced by increasing the size of the sulfonamide alkyl side chain. On the range of the fluorinatedalkylsulfamoylphenyl porphyrins, $\mathbf{6 a - 6 c}$, it is evident that changing the alkyl chain from methyl to ethyl or propyl, the obtained value of $\log K_{\mathrm{OW}}$ is within the experimental error, but sulfonamides with higher carbon atoms on the alkyl chains (6d and $\mathbf{6 e}$ ), were not detectable by fluorescence in the aqueous phase. In the experimental conditions of this study, the detection limit is sub-nanomolar, which requires $\log K_{\mathrm{OW}}>4$. Furthermore the $\log K_{\mathrm{OW}}$ of compounds $4 \mathbf{f f}, \mathbf{5 f}$ and $\mathbf{6 f}$ is always negative.

It is evident that simple and efficient synthetic methods can be used to tune the lipophilicity of sulfonamide porphyrins, by selecting the type and number of halogen atoms as well as the size of the alkyl sulfonamide chain. We note, in passing, that subnanomolar quantities of fluorinated-alkylsulfamoylphenyl porphyrins can be detected in aqueous solution by fluorescence spectroscopy. This can be very useful for diagnosis and adds to the well-known use of fluorinated compounds as probes in magnetic resonance imaging. ${ }^{41-43}$

\section{Conclusions}

The chlorosulfonation of the phenyl ring of ortho-halogenated phenyl porphyrins is a convenient method to prepare high yields of pure and stable chlorosulfonated derivatives. The chlorosulfonyl compounds easily react with the desired amines or water to give a large portfolio of amphiphilic halogenated porphyrins with very good yields. The use of MALDI-TOFMS using the DCTB matrix revealed to be an excellent approach to obtain $\mathrm{M}^{+\cdot}$ for all the sulfonamides without any fragmentation. The determination of 1octanol/water partition coefficients showed that by changing the halogen atom and/or the side chain it is possible to obtain compounds with a wide range of lipophilicities, from $\log K_{\mathrm{OW}}=-2.71$ till $\log K_{\mathrm{OW}}>4$, which are needed to optimize the biological efficacy of this class of sensitizers. Furthermore, the sub-nanomolar quantities of fluorinated-alkylsulfamoylphenyl porphyrins detected by fluorescence spectroscopy enlarge the possibilities of using these sensitizers for in vivo diagnosis.

\section{Experimental}

\subsection{General}

UV-visible absorption spectra were recorded on a Hitachi $U$-2010 in quartz cells. The molar absorption coefficients were determined in toluene and PBS solutions. The fluorescence spectra for the determination of the 1-octanol/water partition coefficient were acquired on a Spex Fluorolog 3 spectrophotometer. Elemental analyses were carried out on a Fisons Instruments EA 1108 CHNS-O elemental analyser. Melting points were measured on an Electrothermal capillary melting point apparatus. ${ }^{1} \mathrm{H}$ NMR and ${ }^{19} \mathrm{~F}$ NMR and ${ }^{13} \mathrm{C}$ NMR spectra were recorded on a $300 \mathrm{MHz}$ Brucker-Amx. ${ }^{1} \mathrm{H}$ assignments were made using 2D COSY and NOESY experiments, while ${ }^{13} \mathrm{C}$ assignments were made using 2D HSQC and HMBC experiments. MALDI-TOFMS data were acquired using an Applied Biosystems Voyager DE-STR instrument (Framingham, MA, USA.), which is equipped with a nitrogen laser $(\lambda=337 \mathrm{~nm})$.
All the solvents used in the synthesis of the sulfonamide halogenated porphyrins were purified by standard methods before use. $^{44}$ The dichloromethane and chloroform used in the column chromatography by silica gel was neutralized with neutral active alumina. All the reactants used for the synthesis of sulfonamide halogenated porphyrins were purchased from Sigma and used as received. The 1-octanol used on the determination of the 1-octanol/ water coefficient partition was obtained from Merck. DCTB and DHB matrices were purchased from Fluka. HPLC grade solvents were used for MALDI-TOFMS analysis; dichloromethane and acetonitrile were purchased from Fischer Scientific, while ethanol was purchased from Sigma-Aldrich.

\subsection{General porphyrin synthesis}

The synthesis of porphyrins $\mathbf{1}, \mathbf{2}$ and $\mathbf{3}$ were carried out by nitrobenzene method ${ }^{21,22}$ prepared by the condensation of the desired halogenated arylaldehyde $(43 \mathrm{mmol})$ with pyrrole $(3 \mathrm{~mL}$, $43 \mathrm{mmol})$ in a mixture of acetic acid $(140 \mathrm{~mL}, 2.45 \mathrm{~mol})$ and nitrobenzene $(70 \mathrm{~mL}, 0.68 \mathrm{~mol})$ at $120^{\circ} \mathrm{C}(1 \mathrm{~h})$. The solution was cooled to room temperature and $50 \mathrm{~mL}$ of methanol was added to promote precipitation. The crystals of the porphyrins were filtered off, washed with methanol and dried. By this method, very pure crystals of porphyrins were obtained without further purification procedures. Porphyrins 1 and $\mathbf{2}$ were obtained with yields 9 and $4.5 \%$, respectively. Their identity was confirmed by NMR, FAB and microanalysis, with good agreement with literature data. ${ }^{21,22}$

5,10,15,20-Tetrakis(2-fluorophenyl)porphyrin 3 was prepared as described above but $1.328 \mathrm{~g}$ (20\%) of pure crystals were obtained.

\subsubsection{5,10,15,20-Tetrakis(2-fluorophenyl)porphyrin (3)}

Yield (1.328 g, 20\%); Mp>300 ${ }^{\circ} \mathrm{C}$; MS (EI), m/z: $686.2086 \mathrm{M}^{+\bullet}$, (calcd for $\mathrm{C}_{44} \mathrm{H}_{26} \mathrm{~N}_{4} \mathrm{~F}_{4}, 686.2088 \mathrm{M}^{+}$); ${ }^{1} \mathrm{H}$ NMR (300 MHz, $\mathrm{CDCl}_{3}$ ) $\delta \mathrm{ppm} 8.84(\mathrm{~s}, 8 \mathrm{H}, \beta-H), 8.15-8.12(\mathrm{~m}, 4 \mathrm{H}, \mathrm{Ph}-H), 7.81-7.78(\mathrm{~m}, 4 \mathrm{H}$, $\mathrm{Ph}-H), 7.58-7.49(\mathrm{~m}, 8 \mathrm{H}, \mathrm{Ph}-\mathrm{H}),-2.78(\mathrm{~s}, 2 \mathrm{H}, \mathrm{NH})$; UV-vis (toluene) $\lambda_{\max } / \mathrm{nm}\left(\varepsilon / \mathrm{M}^{-1} \mathrm{~cm}^{-1}\right) 417\left(5.0 \times 10^{5}\right), 511\left(2.8 \times 10^{4}\right), 543\left(7.3 \times 10^{3}\right)$, $587\left(8.1 \times 10^{3}\right), 653\left(5.4 \times 10^{3}\right)$.

\subsection{General procedure for chlorosulfonation of porphyrins}

Chlorosulfonation of the halogenated porphyrins was carried out according to a method developed previously. ${ }^{25}$ The required porphyrin (200 mg) and chlorosulfonic acid ( $10 \mathrm{~mL}, 150 \mathrm{mmol})$ were stirred at $50{ }^{\circ} \mathrm{C} 1,100{ }^{\circ} \mathrm{C} 2$ and $60^{\circ} \mathrm{C} 3$ for 1,3 and $1.5 \mathrm{~h}$, respectively. After this period, dichloromethane $(200 \mathrm{~mL})$ was added to the solution. A continuous water extraction was carried out, with stirring, until neutralization. The dichloromethane solution was then washed with sodium hydrogen carbonate and dried over anhydrous $\mathrm{Na}_{2} \mathrm{SO}_{4}$. The purification by column chromatography in silica gel using dichloromethane as eluent, and subsequent solvent evaporation yielded the desired chlorosulfonated porphyrins as purple crystals.

\subsubsection{5,10,15,20-Tetrakis(2-chloro-5-chlorosulfonylphenyl)-} porphyrin (4)

Yield (288 mg, 94\%); $\mathrm{Mp}>300{ }^{\circ} \mathrm{C}$; MS (FAB), $m / z: 1147[\mathrm{M}+\mathrm{H}]^{+}$; ${ }^{1} \mathrm{H}$ NMR $\left(300 \mathrm{MHz}, \mathrm{CDCl}_{3}\right) \delta \mathrm{ppm} 8.90-8.76(\mathrm{~m}, 4 \mathrm{H}, \mathrm{Ph}-\mathrm{H}), 8.70$ (s, $8 \mathrm{H}, \beta-H), 8.49-8.46$ ( $\mathrm{m}, 4 \mathrm{H}, \mathrm{Ph}-H), 8.17-8.13(\mathrm{~m}, 4 \mathrm{H}, \mathrm{Ph}-H),-2.71$ $(\mathrm{s}, 2 \mathrm{H}, \mathrm{NH})$; UV-vis (toluene) $\lambda_{\max } / \mathrm{nm}\left(\varepsilon / \mathrm{M}^{-1} \mathrm{~cm}^{-1}\right) 423\left(2.3 \times 10^{5}\right)$, $513\left(1.4 \times 10^{4}\right), 545\left(2.1 \times 10^{3}\right), 589\left(4.2 \times 10^{3}\right), 645\left(5.4 \times 10^{2}\right)$. Anal. Calcd for $\mathrm{C}_{44} \mathrm{H}_{22} \mathrm{~N}_{4} \mathrm{O}_{8} \mathrm{Cl}_{8} \mathrm{~S}_{4} \cdot 2 \mathrm{H}_{2} \mathrm{O}$ : C, 44.69; $\mathrm{H}, 2.22 ; \mathrm{N}, 4.74 ; \mathrm{S}, 10.80$. Found: C, 44.82; H, 2.77; N, 4.24; S, 10.66 .

\subsubsection{5,10,15,20-Tetrakis(2,6-dichloro-3-chlorosulfonylphenyl)- porphyrin (5)}

Yield (264 mg, 92\%); Mp $>300{ }^{\circ} \mathrm{C}$; MS (FAB), $m / z: 1285[\mathrm{M}+\mathrm{H}]^{+}$; ${ }^{1} \mathrm{H}$ NMR $\left(300 \mathrm{MHz}, \mathrm{CDCl}_{3}\right) \delta \mathrm{ppm} 8.67-8.63(\mathrm{~m}, 12 \mathrm{H}, \beta-H$ and 
$\mathrm{Ph}-H), 8.11-8.06(\mathrm{~m}, 4 \mathrm{H}, \mathrm{Ph}-H),-2.51$ (s, 2H, NH); UV-vis (toluene) $\lambda_{\max } / \mathrm{nm}\left(\varepsilon / \mathrm{M}^{-1} \mathrm{~cm}^{-1}\right) 421\left(3.2 \times 10^{5}\right), 514\left(2.1 \times 10^{4}\right), 544\left(2.6 \times 10^{3}\right)$, $590\left(6.7 \times 10^{3}\right), 650\left(8.2 \times 10^{2}\right)$. Anal. Calcd for $\mathrm{C}_{44} \mathrm{H}_{18} \mathrm{~N}_{4} \mathrm{O}_{8} \mathrm{Cl}_{12} \mathrm{~S}_{4}: \mathrm{C}$, 41.15; H, 1.41; N, 4.36. Found: C, 40.70; H, 1.60; N, 4.30.

\subsubsection{5,10,15,20-Tetrakis(2-fluoro-5-chlorosulfonylphenyl)- porphyrin (6)}

Yield (302 mg, 97\%); Mp $>300{ }^{\circ} \mathrm{C}$; MS (MALDI-TOF), $\mathrm{m} / \mathrm{z}: 1079.8$ $\mathrm{M}^{+\bullet} ;{ }^{1} \mathrm{H}$ NMR $\left(300 \mathrm{MHz}, \mathrm{CDCl}_{3}\right) \delta \mathrm{ppm} 8.90-8.86(\mathrm{~m}, 12 \mathrm{H}, \beta-\mathrm{H}$ and $\mathrm{Ph}-H)$, 8.60-8.55 (m, 4H, Ph-H), 7.84-7.79 (m, 4H, Ph-H), -2.84 (s, $2 \mathrm{H}, \mathrm{NH}) ;{ }^{19} \mathrm{~F} \mathrm{NMR}\left(282 \mathrm{MHz}, \mathrm{CDCl}_{3}\right) \delta \mathrm{ppm}-120.93(\mathrm{~m}, 4 \mathrm{~F}, o-\mathrm{F})$; UV-vis (toluene) $\lambda_{\max } / \mathrm{nm}\left(\varepsilon / \mathrm{M}^{-1} \mathrm{~cm}^{-1}\right) \quad 420\left(3.7 \times 10^{5}\right), \quad 511$ $\left(2.4 \times 10^{4}\right), 543\left(4.7 \times 10^{3}\right), 586\left(7.5 \times 10^{3}\right), 643\left(1.1 \times 10^{3}\right)$. Anal. Calcd for $\mathrm{C}_{44} \mathrm{H}_{22} \mathrm{~N}_{4} \mathrm{O}_{8} \mathrm{Cl}_{4} \mathrm{~F}_{4} \mathrm{~S}_{4}$ : C, 48.90; H, 2.05; N, 5.18; S, 11.87. Found: C, 48.06; H, 2.27; N, 5.45; S, 11.90 .

\subsection{General procedure for hydrolysis}

Suspensions of above chlorosulfonated porphyrins (100 mg) in distilled water $(120 \mathrm{~mL})$ were refluxed for $12 \mathrm{~h}$. The resulting solutions were concentrated by rotary evaporation and the solid obtained was dried at $120^{\circ} \mathrm{C}$.

The sulfonic acid porphyrin derivatives 5,10,15,20-tetrakis(2chloro-5-sulfonylphenyl)porphyrin $4 \mathbf{f}$ and 5,10,15,20-tetrakis(2,6dichloro-3-sulfonylphenyl)porphyrin $\mathbf{5 f}$ were obtained with quantitative yields. They were characterized by NMR; FAB and microanalysis, with good agreement with literature data. ${ }^{12,26}$

5,10,15,20-Tetrakis(2-fluoro-5-sulfophenyl)porphyrin $6 \mathbf{6 f}$ was prepared as described above and obtained also with quantitative yield.

\subsubsection{5,10,15,20-Tetrakis(2-fluoro-5-sulfophenyl)porphyrin (6f)}

Compound $6(100 \mathrm{mg}, 0.093 \mathrm{mmol})$ in distilled water was refluxed. Following the procedure described above was obtained the solid of the corresponding sulfonic acid porphyrin derivative $6 \mathbf{6 f}$. Yield (93 mg, 100\%). Mp $>300{ }^{\circ} \mathrm{C}$; MS (MALDI-TOF), $\mathrm{m} / \mathrm{z}: 1007.0$ $[\mathrm{M}+\mathrm{H}]^{+} ;{ }^{1} \mathrm{H}$ NMR $\left(300 \mathrm{MHz}, \mathrm{CD}_{3} \mathrm{OD}\right) \delta \mathrm{ppm} 9.22(\mathrm{~s}, 8 \mathrm{H}, \beta-H)$, 8.63(br s, $4 \mathrm{H}, \mathrm{Ph}-H$ ), 8.32 (br s, $4 \mathrm{H}, \mathrm{Ph}-H$ ), 7.88-782 (m, 4H, Ph-H); UV-vis $\left(\mathrm{H}_{2} \mathrm{O} / \mathrm{PBS}\right) \quad \lambda_{\max } / \mathrm{nm}\left(\varepsilon / \mathrm{M}^{-1} \mathrm{~cm}^{-1}\right) 410\left(4.1 \times 10^{5}\right), \quad 511$ $\left(1.7 \times 10^{4}\right), 547\left(3.4 \times 10^{3}\right), 577\left(6.5 \times 10^{3}\right), 629\left(1.4 \times 10^{3}\right)$.

\subsection{General procedure for the synthesis of sulfonamide halogenated porphyrins}

A sample of chlorosulfonated porphyrin $(0.1 \mathrm{mmol})$ was dissolved in dried dichloromethane $(50 \mathrm{~mL})$, and the amine $(1.2 \mathrm{mmol})$ was added. The reaction mixture was stirred at room temperature for $3 \mathrm{~h}$. The organic phase was then washed with a solution of $\mathrm{HCl} 1 \mathrm{M}(3 \times)$, with a saturated solution of sodium hydrogen carbonate $(2 \times)$, with distilled water $(2 \times)$, and then was dried over anhydrous $\mathrm{Na}_{2} \mathrm{SO}_{4}$. The solvent was concentrated by rotatory evaporation and the resulting solid was purified using silica gel chromatography with $\mathrm{CHCl}_{3} /$ EtOAc (4:1) mixture as eluent. Evaporation of the solvent and recrystallization of the residue using $\mathrm{CH}_{2} \mathrm{Cl}_{2} / \mathrm{CH}_{3} \mathrm{OH}$ or $\mathrm{CH}_{2} \mathrm{Cl}_{2} /$ pentane gave the respective sulfonamide halogenated porphyrin.

\subsubsection{5,10,15,20-Tetrakis(2-chloro-5-N-methylsulfamoylphenyl)- porphyrin (4a)}

Initially, $0.6 \mathrm{~mL}(1.2 \mathrm{mmol})$ of a methylamine solution (THF, $2 \mathrm{M}$ ), was added to 4 (115 $\mathrm{mg}, 0.1 \mathrm{mmol}$ ) previously dissolved in dichloromethane $(50 \mathrm{~mL})$. Following the procedure described above, the solid of $\mathbf{4 a}$ was obtained ( $84 \mathrm{mg}, 75 \%)$. Mp $>300{ }^{\circ} \mathrm{C}$; MS (MALDI-TOF), $m / z$ : $1124.0 \mathrm{M}^{+\cdot} ;{ }^{1} \mathrm{H}$ NMR $\left(300 \mathrm{MHz}, \mathrm{CDCl}_{3}\right) \delta \mathrm{ppm}$ 8.70-8.57 ( $\mathrm{m}, 12 \mathrm{H}, \beta-H$ and $\mathrm{Ph}-\mathrm{H}), 8.29-8.26(\mathrm{~m}, 4 \mathrm{H}, \mathrm{Ph}-\mathrm{H})$, 8.07-8.03 (m, $4 \mathrm{H}, \mathrm{Ph}-\mathrm{H}), 4.63-4.59\left(\mathrm{~m}, 4 \mathrm{H},-\mathrm{NHCH}_{3}\right), 2,81$ (s, $\left.12 \mathrm{H},-\mathrm{NHCH}_{3}\right),-2.72(\mathrm{~s}, 2 \mathrm{H}, \mathrm{NH})$; UV-vis (toluene) $\lambda_{\max } / \mathrm{nm}$ $\left(\varepsilon / \mathrm{M}^{-1} \mathrm{~cm}^{-1}\right) \quad 419\left(2.3 \times 10^{5}\right), \quad 513\left(1.8 \times 10^{4}\right), \quad 544\left(2.8 \times 10^{3}\right)$, $588\left(5.3 \times 10^{3}\right), 645\left(6.8 \times 10^{2}\right)$. Anal. Calcd for $\mathrm{C}_{48} \mathrm{H}_{38} \mathrm{Cl}_{4} \mathrm{~N}_{8} \mathrm{O}_{8} \mathrm{~S}_{4}$ : C, 51.25; H, 3.40; N, 9.96; S, 11.40. Found: C, 51.06; H, 3.47; N, 9.75; S, 11.55 .

\subsubsection{5,10,15,20-Tetrakis(2-chloro-5-N-ethylsulfamoylphenyl)- porphyrin (4b)}

Initially, $0.6 \mathrm{~mL}$ (1.2 mmol) of an ethylamine solution (THF, $2 \mathrm{M}$ ), was added to 4 (115 mg, $0.1 \mathrm{mmol}$ ) previously dissolved in dichloromethane $(50 \mathrm{~mL})$. Following the procedure described above, the solid of $\mathbf{4 b}$ was obtained (109 $\mathrm{mg}, 92 \%)$. Mp $270-271^{\circ} \mathrm{C}$; MS (MALDI-TOF), $m / z: 1180.1 \mathrm{M}^{+*} ;{ }^{1} \mathrm{H}$ NMR $\left(300 \mathrm{MHz}, \mathrm{CDCl}_{3}\right) \delta \mathrm{ppm}$ 8.68-8.54 ( $\mathrm{m}, 12 \mathrm{H}, \beta-H$ and $\mathrm{Ph}-H), 8.26-8.24(\mathrm{~m}, 4 \mathrm{H}, \mathrm{Ph}-H), 7.98-$ $7.82(\mathrm{~m}, 4 \mathrm{H}, \mathrm{Ph}-\mathrm{H}), 4.64-4.61\left(\mathrm{~m}, 4 \mathrm{H},-\mathrm{NHCH}_{2} \mathrm{CH}_{3}\right), 3.26-3.14(\mathrm{~m}$, $\left.8 \mathrm{H},-\mathrm{NHCH}_{2} \mathrm{CH}_{3}\right), 1.25-1.09\left(\mathrm{~m}, 12 \mathrm{H},-\mathrm{NHCH}_{2} \mathrm{CH}_{3}\right),-2.74(\mathrm{~s}, 2 \mathrm{H}$, $\mathrm{NH})$; UV-vis (toluene) $\lambda_{\max } / \mathrm{nm}\left(\varepsilon / \mathrm{M}^{-1} \mathrm{~cm}^{-1}\right) 421\left(3.5 \times 10^{5}\right), 513$ $\left(2.2 \times 10^{4}\right), 542\left(4.6 \times 10^{3}\right), 589\left(6.8 \times 10^{3}\right), 647\left(1.9 \times 10^{3}\right)$. Anal. Calcd for $\mathrm{C}_{52} \mathrm{H}_{46} \mathrm{Cl}_{4} \mathrm{~N}_{8} \mathrm{O}_{8} \mathrm{~S}_{4}$ : C, 52.88; $\mathrm{H}, 3.93 ; \mathrm{N}, 9.49 ; \mathrm{S}, 10.86$. Found: $\mathrm{C}$, 52.59; H, 3.89; N, 9.55; S, 10.90.

\subsubsection{5,10,15,20-Tetrakis(2-chloro-5-N-propylsulfamoylphenyl)- porphyrin $(\mathbf{4 c})$}

Initially, $0.1 \mathrm{~mL}(1.2 \mathrm{mmol})$ of propylamine, was added to 4 (115 $\mathrm{mg}, 0.1 \mathrm{mmol}$ ) previously dissolved in dichloromethane $(50 \mathrm{~mL})$. Following the procedure described above, the solid of $\mathbf{4 c}$ was obtained (96 mg, 78\%). Mp 232-233 ${ }^{\circ} \mathrm{C}$; MS (MALDI-TOF), $m / z$ : $1236.1 \mathrm{M}^{+\bullet} ;{ }^{1} \mathrm{H}$ NMR $\left(300 \mathrm{MHz}, \mathrm{CDCl}_{3}\right) \delta \mathrm{ppm} 8.68-8.56(\mathrm{~m}, 12 \mathrm{H}$, $\beta-H$ and $\mathrm{Ph}-H), 8.27-8.25$ ( $\mathrm{m}, 4 \mathrm{H}, \mathrm{Ph}-H), 8.01-7.96(\mathrm{~m}, 4 \mathrm{H}, \mathrm{Ph}-H)$, 4.65-4.61 (m, 4H, $\left.-\mathrm{NHCH}_{2} \mathrm{CH}_{2} \mathrm{CH}_{3}\right), 3.15-3.09\left(\mathrm{~m}, 8 \mathrm{H},-\mathrm{NHCH}_{2}-\right.$ $\left.\mathrm{CH}_{2} \mathrm{CH}_{3}\right), 1.28-1.23\left(\mathrm{~m}, 8 \mathrm{H},-\mathrm{NHCH}_{2} \mathrm{CH}_{2} \mathrm{CH}_{3}\right), 0.95-0.87(\mathrm{~m}, 12 \mathrm{H}$, $\left.-\mathrm{NHCH}_{2} \mathrm{CH}_{2} \mathrm{CH}_{3}\right),-2.72(\mathrm{~s}, 2 \mathrm{H}, \mathrm{NH})$; UV-vis (toluene) $\lambda$ max $/ \mathrm{nm}$ $\left(\varepsilon / \mathrm{M}^{-1} \mathrm{~cm}^{-1}\right) 419\left(2.3 \times 10^{5}\right), 513\left(1.8 \times 10^{4}\right), 543\left(2.8 \times 10^{3}\right), 588$ $\left(5.3 \times 10^{3}\right), 645\left(6.8 \times 10^{2}\right)$. Anal. Calcd for $\mathrm{C}_{56} \mathrm{H}_{54} \mathrm{Cl}_{4} \mathrm{~N}_{8} \mathrm{O}_{8} \mathrm{~S}_{4}: \mathrm{C}, 54.37$; H, 4.40; N, 9.06; S, 10.37. Found: C, 54.53; H, 4.21; N, 8.95; S, 10.46 .

\subsubsection{5,10,15,20-Tetrakis(2-chloro-5-N-heptylsulfamoylphenyl)- porphyrin (4d)}

Initially, $0.18 \mathrm{~mL}(1.2 \mathrm{mmol})$ of heptylamine, was added to 4 (115 $\mathrm{mg}, \quad 0.1 \mathrm{mmol}$ ) previously dissolved in dichloromethane $(50 \mathrm{~mL})$. Following the procedure described above, the solid of $4 \mathbf{d}$ was obtained (130 mg, 89\%). Mp 195-196 ${ }^{\circ} \mathrm{C}$; MS (MALDI-TOF), $m / z$ : $1460.4 \mathrm{M}^{+\bullet} ;{ }^{1} \mathrm{H}$ NMR $\left(300 \mathrm{MHz}, \mathrm{CDCl}_{3}\right) \delta \mathrm{ppm} 8.68-8.57(\mathrm{~m}, 12 \mathrm{H}$, $\beta-H$ and $\mathrm{Ph}-H), 8.26-8.24(\mathrm{~m}, 4 \mathrm{H}, \mathrm{Ph}-H), 8.00-7.88(\mathrm{~m}, 4 \mathrm{H}, \mathrm{Ph}-H)$, 4.66-4.61 (m, 4H, $\left.-\mathrm{NHCH}_{2}\left(\mathrm{CH}_{2}\right)_{5} \mathrm{CH}_{3}\right), 3.18-3.10\left(\mathrm{~m}, 8 \mathrm{H},-\mathrm{NHCH}_{2}-\right.$ $\left.\left(\mathrm{CH}_{2}\right)_{5} \mathrm{CH}_{3}\right), 1.23-1.19\left(\mathrm{~m}, 40 \mathrm{H},-\mathrm{NHCH}_{2}\left(\mathrm{CH}_{2}\right)_{5} \mathrm{CH}_{3}\right), 0.83-0.76(\mathrm{~m}$, $\left.12 \mathrm{H},-\mathrm{NHCH}_{2}\left(\mathrm{CH}_{2}\right)_{5} \mathrm{CH}_{3}\right),-2.72(\mathrm{~s}, 2 \mathrm{H}, \mathrm{NH}) ; \mathrm{UV}$-vis (toluene) $\lambda_{\max } / \mathrm{nm}\left(\varepsilon / \mathrm{M}^{-1} \mathrm{~cm}^{-1}\right) 420\left(2.3 \times 10^{5}\right), 513\left(1.4 \times 10^{4}\right), 544\left(2.5 \times 10^{3}\right)$, $589\left(4.1 \times 10^{3}\right), 648\left(9.0 \times 10^{2}\right)$. Anal. Calcd for for $\mathrm{C}_{72} \mathrm{H}_{86} \mathrm{Cl}_{4} \mathrm{~N}_{8} \mathrm{O}_{8} \mathrm{~S}_{4}$ : C, 59.17; H, 5.93; N, 7.67; S, 8.78. Found: C, 59.06; H, 6.07; N, 7.65; S, 8.61.

\subsubsection{5,10,15,20-Tetrakis(2-chloro-5-N-piperidylsulfamoylphenyl)- porphyrin (4e)}

Initially, $0.12 \mathrm{~mL}(1.2 \mathrm{mmol})$ of piperidine, was added to 4 (115 mg, $0.1 \mathrm{mmol}$ ) previously dissolved in dichloromethane $(50 \mathrm{~mL})$. Following the procedure described above, the solid of $\mathbf{4 e}$ was obtained $(111 \mathrm{mg}, 83 \%) . \mathrm{Mp}>300^{\circ} \mathrm{C}$; MS (MALDI-TOF), $\mathrm{m} / z$ : $1340.2 \mathrm{M}^{+*} ;{ }^{1} \mathrm{H}$ NMR $\left(300 \mathrm{MHz}, \mathrm{CDCl}_{3}\right) \delta \mathrm{ppm} 8.65(\mathrm{~s}, 8 \mathrm{H}, \beta-H)$, 8.60-8.49 (m, 4H, Ph-H) 8.18-8.16 (m, 4H, Ph-H), 8.04-8.00 (m, $4 \mathrm{H}, \mathrm{Ph}-\mathrm{H}$ ), 3.21 (br s, $\left.16 \mathrm{H},-\mathrm{N}\left(\mathrm{CH}_{2}\right)_{2}\left(\mathrm{CH}_{2}\right)_{3}\right), 1.59$ (br s, $24 \mathrm{H}$, $\left.-\mathrm{N}\left(\mathrm{CH}_{2}\right)_{2}\left(\mathrm{CH}_{2}\right)_{3}\right),-2.70(\mathrm{~s}, 2 \mathrm{H}, \mathrm{NH}) ; \mathrm{UV}$-vis (toluene) $\lambda_{\max } / \mathrm{nm}$ $\left(\varepsilon / \mathrm{M}^{-1} \mathrm{~cm}^{-1}\right) 420\left(6.4 \times 10^{5}\right) ; 513\left(3.4 \times 10^{4}\right) ; 544 \quad\left(6.3 \times 10^{3}\right)$; $588\left(1.1 \times 10^{4}\right) ; 645\left(1.7 \times 10^{2}\right)$. Anal. Calcd for $\mathrm{C}_{64} \mathrm{H}_{62} \mathrm{Cl}_{4} \mathrm{~N}_{8} \mathrm{O}_{8} \mathrm{~S}_{4}$ : C, 57.31; H, 4.66; N, 8.35; S, 9.56 Found: C, 57.85; H, 4.48; N, 8.23; S, 9.21. 
4.5.6. 5,10,15,20-Tetrakis(2,6-dichloro-3-N-methylsulfamoylphenyl)porphyrin (5a)

Initially, $0.6 \mathrm{~mL}(1.2 \mathrm{mmol})$ of a methylamine solution (THF, $2 \mathrm{M}$ ), was added to 5 (128 $\mathrm{mg}, 0.1 \mathrm{mmol}$ ) previously dissolved in dichloromethane $(50 \mathrm{~mL})$. Following the procedure described above, the solid of $\mathbf{5 a}$ was obtained $(129 \mathrm{mg}, 94 \%)$. Mp $>300{ }^{\circ} \mathrm{C}$; MS (MALDI-TOF), $m / z: 1261.9 \mathrm{M}^{+\cdot} ;{ }^{1} \mathrm{H}$ NMR $\left(300 \mathrm{MHz}, \mathrm{CDCl}_{3}\right) \delta \mathrm{ppm}$ 8.63-8.57 $(\mathrm{m}, 12 \mathrm{H}, \beta-H$ and $\mathrm{Ph}-H), 8.03-7.99(\mathrm{~m}, 4 \mathrm{H}, \mathrm{Ph}-H)$, 5.02-4.99 (m, 4H, $\left.-\mathrm{NHCH}_{3}\right), 2.89\left(\mathrm{~s}, 12 \mathrm{H},-\mathrm{NHCH}_{3}\right),-2.55(\mathrm{~s}, 2 \mathrm{H}$, $\mathrm{NH})$; UV-vis (toluene) $\lambda_{\max } / \mathrm{nm}\left(\varepsilon / \mathrm{M}^{-1} \mathrm{~cm}^{-1}\right) 421\left(2.6 \times 10^{5}\right), 515$ $\left(1.7 \times 10^{4}\right), 552\left(2.4 \times 10^{3}\right), 595\left(5.3 \times 10^{3}\right), 654\left(1.2 \times 10^{3}\right)$. Anal. Calcd for $\mathrm{C}_{48} \mathrm{H}_{34} \mathrm{Cl}_{8} \mathrm{~N}_{8} \mathrm{O}_{8} \mathrm{~S}_{4}$ : C, 45.66; $\mathrm{H}, 2.71 ; \mathrm{N}, 8.87 ; \mathrm{S}, 10.16$. Found: $\mathrm{C}$, 46.06; H, 2.57; N, 8.75; S, 9.85.

\subsubsection{5,10,15,20-Tetrakis(2,6-dichloro-3-N-ethylsulfamoyl-}

phenyl)porphyrin (5b)

Initially, $0.6 \mathrm{~mL}(1.2 \mathrm{mmol})$ of an ethylamine solution (THF, $2 \mathrm{M}$ ), was added to 5 (128 $\mathrm{mg}, 0.1 \mathrm{mmol})$ previously dissolved in dichloromethane $(50 \mathrm{~mL})$. Following the procedure described above, the solid of $\mathbf{5 b}$ was obtained (126 mg, 96\%). Mp 298-299 ${ }^{\circ} \mathrm{C}$; MS (MALDI-TOF), $m / z: 1317.9 \mathrm{M}^{+\cdot} ;{ }^{1} \mathrm{H}$ NMR (300 MHz, $\left.\mathrm{CDCl}_{3}\right) \delta \mathrm{ppm}$ 8.64-8.36 ( $\mathrm{m}, 12 \mathrm{H}, \beta-H$ and $\mathrm{Ph}-\mathrm{H}), 8.00-7.95(\mathrm{~m}, 4 \mathrm{H}, \mathrm{Ph}-\mathrm{H}), 5.11-$ $5.03\left(\mathrm{~m}, 4 \mathrm{H},-\mathrm{NHCH}_{2} \mathrm{CH}_{3}\right), 3.29-3.09\left(\mathrm{~m}, 8 \mathrm{H},-\mathrm{NHCH}_{2} \mathrm{CH}_{3}\right), 1.18-$ $1.15\left(\mathrm{~m}, 12 \mathrm{H},-\mathrm{NHCH}_{2} \mathrm{CH}_{3}\right),-2.55(\mathrm{~s}, 2 \mathrm{H}, \mathrm{NH})$; UV-vis (toluene) $\lambda_{\max } /$ $\mathrm{nm}\left(\varepsilon / \mathrm{M}^{-1} \mathrm{~cm}^{-1}\right) 421\left(2.4 \times 10^{5}\right), 516\left(1.7 \times 10^{4}\right), 549\left(3.8 \times 10^{3}\right), 597$ $\left(6.1 \times 10^{3}\right), 652\left(5.2 \times 10^{3}\right)$. Anal. Calcd for $\mathrm{C}_{52} \mathrm{H}_{42} \mathrm{Cl}_{8} \mathrm{~N}_{8} \mathrm{O}_{8} \mathrm{~S}_{4}$ : C, 47.36; H, 3.21; N, 8.50; S, 9.73. Found: C, 47.21; H, 3.27; N 8.48; S, 9.75.

\subsubsection{5,10,15,20-Tetrakis(2,6-dichloro-3-N-propylsulfamoyl-} phenyl)porphyrin (5c)

Initially, $0.1 \mathrm{~mL}(1.2 \mathrm{mmol})$ of propylamine, was added to 5 (128 $\mathrm{mg}, \quad 0.1 \mathrm{mmol}$ ) previously dissolved in dichloromethane $(50 \mathrm{~mL})$. Following the procedure described above, the solid of $\mathbf{5 c}$ was obtained (122 mg, 89\%). Mp 259-260 ${ }^{\circ} \mathrm{C}$; MS (MALDI-TOF), $m / z: 1374.0 \mathrm{M}^{+} \cdot{ }^{1} \mathrm{H}$ NMR $\left(300 \mathrm{MHz}, \mathrm{CDCl}_{3}\right) \delta \mathrm{ppm} 8.60(\mathrm{~s}, 8 \mathrm{H}, \beta-H)$, $8.58(\mathrm{~d}, J=8.7 \mathrm{~Hz}, 4 \mathrm{H}, \mathrm{Ph}-H), 7.99(\mathrm{~d}, J=8.7 \mathrm{~Hz}, 4 \mathrm{H}, \mathrm{Ph}-H), 5.05-5.09$ $\left(\mathrm{m}, 4 \mathrm{H},-\mathrm{NHCH}_{2} \mathrm{CH}_{2} \mathrm{CH}_{3}\right), 3.22-3.15\left(\mathrm{~m}, 8 \mathrm{H},-\mathrm{NHCH}_{2} \mathrm{CH}_{2} \mathrm{CH}_{3}\right), 1.69-$ $1.61\left(\mathrm{~m}, 8 \mathrm{H},-\mathrm{NHCH}_{2} \mathrm{CH}_{2} \mathrm{CH}_{3}\right), 1.02-0.96\left(\mathrm{~m}, 12 \mathrm{H},-\mathrm{NHCH}_{2} \mathrm{CH}_{2} \mathrm{CH}_{3}\right)$, $-2.55(\mathrm{~s}, 2 \mathrm{H}, \mathrm{NH})$; UV-vis (toluene) $\lambda_{\max } / \mathrm{nm}\left(\varepsilon / \mathrm{M}^{-1} \mathrm{~cm}^{-1}\right) 420$ $\left(4.1 \times 10^{5}\right), \quad 514\left(2.3 \times 10^{4}\right), \quad 541\left(3.3 \times 10^{3}\right), \quad 595\left(7.5 \times 10^{3}\right), \quad 649$ $\left(9.2 \times 10^{2}\right)$. Anal. Calcd for $\mathrm{C}_{56} \mathrm{H}_{50} \mathrm{Cl}_{8} \mathrm{~N}_{8} \mathrm{O}_{8} \mathrm{~S}_{4}: \mathrm{C}, 48.92 ; \mathrm{H}, 3.67 ; \mathrm{N}$, 8.15; S, 9.33. Found: C, 49.05; H, 3.71; N, 7.95; S, 9.21.

\subsubsection{5,10,15,20-Tetrakis(2,6-dichloro-3-N-heptylsulfamoyl-} phenyl)porphyrin (5d)

Initially, $0.18 \mathrm{~mL}(1.2 \mathrm{mmol})$ of heptylamine, was added to $\mathbf{5}$ (128 $\mathrm{mg}, \quad 0.1 \mathrm{mmol}$ ) previously dissolved in dichloromethane (50 $\mathrm{mL}$ ). Following the procedure described above, the solid of $\mathbf{5 d}$ was obtained (134 mg, $84 \%$ ). Mp $140-141^{\circ} \mathrm{C}$; MS (MALDI-TOF), $\mathrm{m} / \mathrm{z}$ : $1598.3 \mathrm{M}^{+*} ;{ }^{1} \mathrm{H}$ NMR (300 MHz, $\left.\mathrm{CDCl}_{3}\right) \delta \mathrm{ppm} 8.60(\mathrm{~s}, 8 \mathrm{H}, \beta-H), 8.58$ $(\mathrm{d}, J=8.6 \mathrm{~Hz}, 4 \mathrm{H}, \mathrm{Ph}-H), 7.94(\mathrm{~d}, J=8.6 \mathrm{~Hz}, 4 \mathrm{H}, \mathrm{Ph}-H), 5.05-5.03(\mathrm{~m}$, $\left.4 \mathrm{H},-\mathrm{NHCH} \mathrm{CH}_{2}\left(\mathrm{CH}_{2}\right)_{5} \mathrm{CH}_{3}\right), 3.23-3.17\left(\mathrm{~m}, 8 \mathrm{H},-\mathrm{NHCH}_{2}\left(\mathrm{CH}_{2}\right)_{5} \mathrm{CH}_{3}\right), 1.34-$ $1.24\left(\mathrm{~m}, 40 \mathrm{H},-\mathrm{NHCH}_{2}\left(\mathrm{CH}_{2}\right)_{5} \mathrm{CH}_{3}\right), 0.86-0.83\left(\mathrm{~m}, 12 \mathrm{H},-\mathrm{NHCH}_{2}-\right.$ $\left.\left(\mathrm{CH}_{2}\right)_{5} \mathrm{CH}_{3}\right),-2.54(\mathrm{~s}, 2 \mathrm{H}, \mathrm{NH}) ; \mathrm{UV}$-vis (toluene) $\lambda_{\max } / \mathrm{nm}(\varepsilon /$ $\left.\mathrm{M}^{-1} \mathrm{~cm}^{-1}\right) 422\left(2.8 \times 10^{5}\right), 514\left(4.2 \times 10^{4}\right), 548\left(1.5 \times 10^{3}\right), 590(3.0 \times$ $\left.10^{3}\right), 648\left(3.9 \times 10^{2}\right)$. Anal. Calcd for for $\mathrm{C}_{72} \mathrm{H}_{82} \mathrm{Cl}_{8} \mathrm{~N}_{8} \mathrm{O}_{8} \mathrm{~S}_{4}$ : C, 54.07; H, 5.17; N, 7.01; S, 8.02. Found: C, 54.18; H, 5.22; N, 6.90; S, 8.04.

\subsubsection{5,10,15,20-Tetrakis(2,6-dichloro-3-N-piperidylsulfamoyl-} phenyl)porphyrin (5e)

Initially, $0.12 \mathrm{~mL}(1.2 \mathrm{mmol})$ of piperidine, was added to 5 $(128 \mathrm{mg}, \quad 0.1 \mathrm{mmol})$ previously dissolved in dichloromethane $(50 \mathrm{~mL})$. Following the procedure described above, the solid of $\mathbf{5 e}$ was obtained ( $140 \mathrm{mg}, 95 \%) . \mathrm{Mp}>300^{\circ} \mathrm{C}$; MS (MALDI-TOF), $\mathrm{m} / z$ : 1478.1 $\mathrm{M}^{+\bullet} ;{ }^{1} \mathrm{H}$ NMR $\left(300 \mathrm{MHz}, \mathrm{CDCl}_{3}\right) \delta \mathrm{ppm} 8.60(\mathrm{~s}, 8 \mathrm{H}, \beta-H), 8.54$ (d, $J=8.6 \mathrm{~Hz}, 4 \mathrm{H}, \mathrm{Ph}-H$ ), 7.94 (d, $J=8.6 \mathrm{~Hz}, 4 \mathrm{H}, \mathrm{Ph}-H$ ), 3.41 (br s, $16 \mathrm{H}$,
$\left.-\mathrm{N}\left(\mathrm{CH}_{2}\right)_{2}\left(\mathrm{CH}_{2}\right)_{3}\right), 1.58$ (br s, $\left.24 \mathrm{H},-\mathrm{N}\left(\mathrm{CH}_{2}\right)_{2}\left(\mathrm{CH}_{2}\right)_{3}\right),-2.54(\mathrm{~s}, 2 \mathrm{H}$, $\mathrm{NH})$; UV-vis (toluene) $\lambda_{\max } / \mathrm{nm}\left(\varepsilon / \mathrm{M}^{-1} \mathrm{~cm}^{-1}\right) 420\left(4.7 \times 10^{5}\right), 514$ $\left(2.6 \times 10^{4}\right), 541\left(3.7 \times 10^{3}\right), 591\left(8.3 \times 10^{3}\right), 647\left(1.1 \times 10^{3}\right)$. Anal. Calcd for $\mathrm{C}_{64} \mathrm{H}_{58} \mathrm{Cl}_{8} \mathrm{~N}_{8} \mathrm{O}_{8} \mathrm{~S}_{4}$ : C, 51.97; $\mathrm{H}, 3.95 ; \mathrm{N}, 7.58 ; \mathrm{S}, 8.67$. Found: $\mathrm{C}$, $52.01 ; \mathrm{H}, 4.03 ; \mathrm{N}, 7.35 ; \mathrm{S}, 8.81$.

\subsubsection{5,10,15,20-Tetrakis(2-fluoro-5-N-methylsulfamoylphenyl)- porphyrin (6a)}

Initially, $0.6 \mathrm{~mL}(1.2 \mathrm{mmol})$ of a methylamine solution (THF, $2 \mathrm{M}$ ), was added to $\mathbf{6}$ (108 $\mathrm{mg}$; $0.1 \mathrm{mmol}$ ) previously dissolved in dichloromethane $(50 \mathrm{~mL})$. Following the procedure described above, the solid of $\mathbf{6 a}$ was obtained (82 $\mathrm{mg}$, 78\%). Mp 298-299 ${ }^{\circ} \mathrm{C}$; MS (MALDI-TOF), $m / z$ : $1058.2 \mathrm{M}^{+\cdot} ;{ }^{1} \mathrm{H}$ NMR $\left(300 \mathrm{MHz}, \mathrm{CDCl}_{3}\right.$ ) $\delta \mathrm{ppm} 8.80(\mathrm{~s}, 8 \mathrm{H}, \beta-H), 8.68-8.58(\mathrm{~m}, 4 \mathrm{H}, \mathrm{Ph}-H), 8.37-8.33(\mathrm{~m}, 4 \mathrm{H}$, $\mathrm{Ph}-\mathrm{H})$, 7.72-7.61 (m, 4H, Ph-H), 4.60-4.57 ( $\left.\mathrm{m}, 4 \mathrm{H},-\mathrm{NHCH}_{3}\right), 2.88-$ $2.82\left(\mathrm{~m}, 12 \mathrm{H},-\mathrm{NHCH}_{3}\right),-2.86(\mathrm{~s}, 2 \mathrm{H}, \mathrm{NH})$; UV-vis (toluene) $\lambda_{\max } /$ $\mathrm{nm}\left(\varepsilon / \mathrm{M}^{-1} \mathrm{~cm}^{-1}\right) 419\left(1.5 \times 10^{5}\right), 512\left(8.4 \times 10^{3}\right), 543\left(1.5 \times 10^{3}\right), 589$ $\left(2.2 \times 10^{3}\right), 645\left(4.4 \times 10^{2}\right)$. Anal. Calcd for $\mathrm{C}_{48} \mathrm{H}_{38} \mathrm{~F}_{4} \mathrm{~N}_{8} \mathrm{O}_{8} \mathrm{~S}_{4}$ : C, 54.43; H, 3.62; N, 10.58; S, 12.11. Found: C, 54.24; H, 3.74; N, 10.76; S, 11.91 .

\subsubsection{5,10,15,20-Tetrakis(2-fluoro-5-N-ethylsulfamoylphenyl)- porphyrin (6b)}

Initially, $0.6 \mathrm{~mL}(1.2 \mathrm{mmol})$ of an ethylamine solution (THF, $2 \mathrm{M})$, was added to $6(108 \mathrm{mg} ; 0.1 \mathrm{mmol})$ previously dissolved in dichloromethane $(50 \mathrm{~mL})$. Following the procedure described above, the solid of $\mathbf{6 b}$ was obtained ( $95 \mathrm{mg}, 85 \%) . \mathrm{Mp}>300^{\circ} \mathrm{C}$; MS (MALDI-TOF), $m / z: 1114.2 \mathrm{M}^{+\bullet} ;{ }^{1} \mathrm{H}$ NMR $\left(300 \mathrm{MHz}, \mathrm{CDCl}_{3}\right) \delta \mathrm{ppm}$ $8.79(\mathrm{~s}, 8 \mathrm{H}, \beta-H), 8.66-8.62$ ( $\mathrm{m}, 4 \mathrm{H}, \mathrm{Ph}-H), 8.36-8.32$ (m, 4H, Ph- $H$ ), 7.70-7.62 (m, 4H, Ph-H), 4.64-4.59 (m, 4H, $\left.-\mathrm{NHCH}_{2} \mathrm{CH}_{3}\right), 3.27-3.19$ $\left(\mathrm{m}, 8 \mathrm{H},-\mathrm{NHCH}_{2} \mathrm{CH}_{3}\right), 1.28-1.17\left(\mathrm{~m}, 12 \mathrm{H},-\mathrm{NHCH}_{2} \mathrm{CH}_{3}\right),-2.86(\mathrm{~s}, 2 \mathrm{H}$, $\mathrm{NH}) ;{ }^{19} \mathrm{~F}$ NMR $\left(282 \mathrm{MHz}, \mathrm{CDCl}_{3}\right),-127.00(\mathrm{~m}, 4 \mathrm{~F}, o-\mathrm{F})$; UV-vis (toluene) $\lambda_{\max } / \mathrm{nm}\left(\varepsilon / \mathrm{M}^{-1} \mathrm{~cm}^{-1}\right) 419\left(3.3 \times 10^{5}\right), 512\left(1.9 \times 10^{4}\right), 544$ $\left(2.3 \times 10^{3}\right), \quad 588\left(5.7 \times 10^{3}\right), \quad 646\left(1.5 \times 10^{3}\right)$. Anal. Calcd for $\mathrm{C}_{52} \mathrm{H}_{46} \mathrm{~F}_{4} \mathrm{~N}_{8} \mathrm{O}_{8} \mathrm{~S}_{4}$ : C, 56.00; H, 4.16; N, 10.05; S, 11.50. Found: C, 56.57; H. 4.27; N, 9.92; S, 10.91.

\subsubsection{5,10,15,20-Tetrakis(2-fluoro-5-N-propylsulfamoylphenyl)- porphyrin (6c)}

Initially, $0.1 \mathrm{~mL}(1.2 \mathrm{mmol})$ of propylamine, was added to $\mathbf{6}$ (108 $\mathrm{mg} ; 0.1 \mathrm{mmol}$ ) previously dissolved in dichloromethane $(50 \mathrm{~mL})$. Following the procedure described above, the solid of $\mathbf{6 c}$ was obtained (96 mg, 82\%). Mp 210-211 ${ }^{\circ} \mathrm{C}$; MS (MALDI-TOF), $m / z$ : $1170.3 \mathrm{M}^{+\cdot} ;{ }^{1} \mathrm{H}$ NMR $\left(300 \mathrm{MHz}, \mathrm{CDCl}_{3}\right) \delta \mathrm{ppm} 8.78(\mathrm{~s}, 8 \mathrm{H}, \beta-H), 8.65-$ $8.62(\mathrm{~m}, 4 \mathrm{H}, \mathrm{Ph}-\mathrm{H}), 8.34-8.30(\mathrm{~m}, 4 \mathrm{H}, \mathrm{Ph}-\mathrm{H}), 7.65-7.59(\mathrm{~m}, 4 \mathrm{H}$, $\mathrm{Ph}-\mathrm{H})$, 4.73-4.67 (m, 4H, $\left.-\mathrm{NHCH}_{2} \mathrm{CH}_{2} \mathrm{CH}_{3}\right), 3.17-3.09(\mathrm{~m}, 8 \mathrm{H}$, $\left.-\mathrm{NHCH}_{2} \mathrm{CH}_{2} \mathrm{CH}_{3}\right), 1.61-1.51\left(\mathrm{~m}, 8 \mathrm{H},-\mathrm{NHCH}_{2} \mathrm{CH}_{2} \mathrm{CH}_{3}\right), 0.96-0.84(\mathrm{~m}$, $\left.12 \mathrm{H},-\mathrm{NHCH}_{2} \mathrm{CH}_{2} \mathrm{CH}_{3}\right),-2.87(\mathrm{~s}, 2 \mathrm{H}, \mathrm{NH})$; UV-vis (toluene) $\lambda_{\max } / \mathrm{nm}$ $\left(\varepsilon / \mathrm{M}^{-1} \mathrm{~cm}^{-1}\right) 418\left(3.8 \times 10^{5}\right), 511\left(2.8 \times 10^{4}\right), 543\left(6.0 \times 10^{3}\right), 586$ $\left(8.6 \times \times 10^{3}\right), 644\left(1.6 \times 10^{3}\right)$. Anal. Calcd for $\mathrm{C}_{56} \mathrm{H}_{54} \mathrm{~F}_{4} \mathrm{~N}_{8} \mathrm{O}_{8} \mathrm{~S}_{4}$ : C, 57.42; H, 4.65; N, 9.57; S, 10.95. Found: C, 57.47; H, 4.54; N, 9.65; S, 10.83 .

\subsubsection{5,10,15,20-Tetrakis(2-fluoro-5-N-heptylsulfamoylphenyl)- porphyrin $(\mathbf{6 d})$}

Initially, $0.18 \mathrm{~mL}(1.2 \mathrm{mmol})$ of heptylamine, was added to $6(108 \mathrm{mg} ; 0.1 \mathrm{mmol}$ ) previously dissolved in dichloromethane $(50 \mathrm{~mL})$. Following the procedure described above, the solid of $\mathbf{6 d}$ was obtained (104 mg, 81\%). Mp 134-135 ${ }^{\circ} \mathrm{C}$; MS (MALDI-TOF), $\mathrm{m} / z$ : $1394.5 \mathrm{M}^{+\cdot}$; ${ }^{1} \mathrm{H}$ NMR $\left(300 \mathrm{MHz}, \mathrm{CDCl}_{3}\right) \delta \mathrm{ppm} 8.79(\mathrm{~s}, 8 \mathrm{H}, \beta-H)$, 8.67-8.63 (m, 4H, Ph-H), 8.36-8.35 (m, 4H, Ph-H), 7.70-7.61 (m, $4 \mathrm{H}, \mathrm{Ph}-\mathrm{H}), 4.63-4.59\left(\mathrm{~m}, 4 \mathrm{H},-\mathrm{NHCH}_{2}\left(\mathrm{CH}_{2}\right)_{5} \mathrm{CH}_{3}\right), 3.20-3.14(\mathrm{~m}, 8 \mathrm{H}$, $\left.-\mathrm{NHCH}_{2}\left(\mathrm{CH}_{2}\right)_{5} \mathrm{CH}_{3}\right), 1.28-1.21\left(\mathrm{~m}, 40 \mathrm{H},-\mathrm{NHCH}_{2}\left(\mathrm{CH}_{2}\right)_{5} \mathrm{CH}_{3}\right), 0.88-$ $0.79\left(\mathrm{~m}, 12 \mathrm{H},-\mathrm{NHCH}_{2}\left(\mathrm{CH}_{2}\right)_{5} \mathrm{CH}_{3}\right),-2.87(\mathrm{~s}, 2 \mathrm{H}, \mathrm{NH})$; UV-vis (toluene) $\lambda_{\max } / \mathrm{nm}\left(\varepsilon / \mathrm{M}^{-1} \mathrm{~cm}^{-1}\right) 419\left(1.6 \times 10^{5}\right), 512\left(1.1 \times 10^{4}\right)$, $542\left(2.7 \times 10^{3}\right), 587\left(3.6 \times 10^{3}\right), 644\left(9.2 \times 10^{2}\right)$. Anal. Calcd for $\mathrm{C}_{72} \mathrm{H}_{86} \mathrm{~F}_{4} \mathrm{~N}_{8} \mathrm{O}_{8} \mathrm{~S}_{4}$ : C, 61.96; H, 6.21; N, 8.03; S, 9.19. Found: C, 61.74; H, 6.33; N, 7.83; S, 9.31. 


\subsubsection{5,10,15,20-Tetrakis(2-fluoro-5-N-piperidylsulfamoyl- phenyl)porphyrin (6e)}

Initially, $0.12 \mathrm{~mL}$ (1.2 mmol) of piperidine, was added $\mathbf{6}$ (108 mg; $0.1 \mathrm{mmol}$ ) previously dissolved in dichloromethane $(50 \mathrm{~mL})$. Following the procedure described above, the solid of $\mathbf{6 e}$ was obtained (113 mg, 82\%). Mp 228-229 ${ }^{\circ} \mathrm{C}$; MS (MALDI-TOF), $m / z: 1274.3 \mathrm{M}^{+*}$; ${ }^{1} \mathrm{H}$ NMR $\left(300 \mathrm{MHz}, \mathrm{CDCl}_{3}\right) \delta \mathrm{ppm} 8.81(\mathrm{~s}, 8 \mathrm{H}, \beta-H), 8.62-8.55(\mathrm{~m}$, $4 \mathrm{H}, \mathrm{Ph}-\mathrm{H}) 8.29-8.23(\mathrm{~m}, 4 \mathrm{H}, \mathrm{Ph}-H), 7.73-7.68(\mathrm{~m}, 4 \mathrm{H}, \mathrm{Ph}-H), 3.22$ (br s, $\left.16 \mathrm{H},-\mathrm{N}\left(\mathrm{CH}_{2}\right)_{2}\left(\mathrm{CH}_{2}\right)_{3}\right), 1.60$ (br s, $\left.24 \mathrm{H},-\mathrm{N}\left(\mathrm{CH}_{2}\right)_{2}\left(\mathrm{CH}_{2}\right)_{3}\right),-2.83$ $(\mathrm{s}, 2 \mathrm{H}, \mathrm{NH}) ;{ }^{19} \mathrm{~F}$ NMR $\left(282 \mathrm{MHz}, \mathrm{CDCl}_{3}\right) \delta \mathrm{ppm}-127.05(\mathrm{~m}, 4 \mathrm{~F}, \mathrm{o}-\mathrm{F})$; UV-vis (toluene) $\lambda_{\max } / \mathrm{nm}\left(\varepsilon / \mathrm{M}^{-1} \mathrm{~cm}^{-1}\right) \quad 418 \quad\left(4.6 \times 10^{5}\right), \quad 511$ $\left(3.6 \times 10^{4}\right), 544\left(7.2 \times 10^{3}\right), 587\left(1.1 \times 10^{4}\right), 643\left(1.8 \times 10^{3}\right)$. Anal. Calcd for $\mathrm{C}_{64} \mathrm{H}_{62} \mathrm{~F}_{4} \mathrm{~N}_{8} \mathrm{O}_{8} \mathrm{~S}_{4}$ : C, 60.27; $\mathrm{H}, 4.90 ; \mathrm{N}, 8.79 ; \mathrm{S}, 10.06$. Found: $\mathrm{C}$, $60.08 ; \mathrm{H}, 4.67 ; \mathrm{N}, 8.54 ; \mathrm{S}, 10.75$.

\subsection{1-Octanol/water partition coefficients}

The 1-octanol/water partition coefficients were measured following shake-flask method with minor modifications. ${ }^{38-40}$ The sulfonamide halogenated porphyrin $\left(8 \times 10^{-2} \mu \mathrm{mol}\right)$ is dissolved in $5 \mathrm{~mL}$ of 1 -octanol previously saturated with a solution of PBS $\mathrm{pH}=7.4$. The same volume ( $5 \mathrm{~mL}$ ) of a PBS solution, saturated with 1 -octanol, was added to the 1-octanol phase, mixed vigorously for $3 \mathrm{~min}$ and then the phases were separated by centrifugation (4000 rpm, $2 \mathrm{~min}$ ). Longer contact times between the phases were tested and shown not to influence the final results. One aliquot of $3 \mathrm{~mL}$ was taken from each phase and diluted with ethanol in order to attain the ratio ethanol/1-octanol (70:30) or ethanol/PBS (70:30). The fluorescence of each ethanol/1-octanol and ethanol/PBS solution was measured, and compared with a calibration curve to obtain the concentration of the photosensitizer. The solutions for the calibration curves were either ethanol/1-octanol (70:30) or ethanol/PBS (70:30), and were both prepared in a range of concentrations between $0.1 \mu \mathrm{M}$ and $1 \mu \mathrm{M}$. The Soret absorption band ca. $420 \mathrm{~nm}$ was excited, and the fluorescence was collected in the red region, under the same instrumental conditions for both the solutions of the calibration curve and the samples. The determination of $\log K_{\mathrm{OW}}$ for the sulfonic acid porphyrin derivatives, $4 \mathbf{4 f}, \mathbf{5 f}$ and $\mathbf{6 f}$, was carried out like the procedure described above, but initially the sensitizers have been dissolved in PBS solution previously saturated with 1-octanol.

The partition coefficients were calculated from the ratio $C_{\text {oct }} /$ $C_{\mathrm{PBS}}$, where $C_{\mathrm{oct}}$ and $C_{\mathrm{PBS}}$ are the concentrations of the porphyrin in the 1-octanol and in the PBS, respectively. All the measurements were carried out at room temperature.

\subsection{MALDI-TOFMS}

DCTB matrix solution was made to a concentration of $20 \mathrm{mg} \mathrm{mL}^{-1}$ in dichloromethane. DHB matrix solution was made to a concentration of $10 \mathrm{mg} \mathrm{mL}^{-1}$ in $1: 1(\mathrm{v} / \mathrm{v}) \mathrm{EtOH} / \mathrm{MeCN}$. All compounds were dissolved in dicloromethane, with the exception of $\mathbf{6 f}$, which was dissolved in $\mathrm{EtOH}$, at an approximate concentration of $10 \mathrm{mg} \mathrm{mL}^{-1}$. One microlitre of sample solution was vortex-mixed with $49 \mu \mathrm{L}$ of DCTB solution; $0.5 \mu \mathrm{L}$ of the final mixture was spotted onto the gold-plated, deep-welled, target plate and allowed to dry. Compound $6 \mathbf{f}$ was analyzed using a similar procedure, but with DHB matrix and a stainless steel target plate. The MALDI-TOFMS spectrometer was operated in positive ion, reflectron mode, and spectra were accumulated in multiples of 25 laser shots, with 100 shots in total. Postacquisition processing of data was performed utilizing Data Explorer V4.0 software supplied by Applied Biosystems. Theoretical isotope distributions were generated at a resolution of $15,000 \mathrm{fwhm}$.

\section{Acknowledgements}

The authors thank Câmara Municipal de Coimbra, Comissão de Coordenação e Desenvolvimento Regional do Centro, Bluepharma SA, Programa Operacional da Região Centro, Medida 1.5 Feder, FCT (PTDC/QUI/66015/2006) for financial support. C.J.P.M., S.M.A.P., A.V.C.S. and G.F.F.S. thank Câmara Municipal de Coimbra for grants. C.J.P.M. also thanks FCT for a PhD grant SFRH/BD/37652/2007.

\section{References and notes}

1. Vicente, M. G. H. Curr. Med. Chem. Anticancer Agents 2001, 1, 175-194.

2. Pineiro, M.; Carvalho, A. L.; Pereira, M. M.; Gonsalves, A. M. d'A. R.; Arnaut, L. G.; Formosinho, S. J. Chem.-Eur. J. 1998, 4, 2299-2307.

3. Sergeeva, N. N.; Senge, O. M. Tetrahedron Lett. 2006, 47, 6169-6172.

4. Pineiro, M.; Pereira, M. M.; Gonsalves, A. M. d'A. R.; Arnaut, L. G.; Formosinho, S. J. J. Photochem. Photobiol., A 2001, 138, 147-157.

5. Chen, Y.; Li, G.; Pandey, R. K. Curr. Org. Chem. 2004, 8, 1105-1134.

6. Pineiro, M.; Gonsalves, A. M. d'A. R.; Pereira, M. M.; Formosinho, S. J.; Arnaut, L G. J. Phys. Chem. A 2002, 106, 3787-3795.

7. Detty, M. R.; Gibson, S. L.; Wagner, S. J. J. Med. Chem. 2004, 47, 3897-3915.

8. Nyman, E. S.; Hynninen, P. H. J. Photochem. Photobiol., B 2004, 73, 1-28.

9. Dolmans, D. E. J. G. J.; Fukumura, D.; Jain, R. K. Nat. Rev. Cancer 2003, 3, 380-387.

10. Allen, C. M.; Sharman, W. M.; van Lier, J. E. J. Porphyrins Phthalocyanines 2001, 5 , 161-169.

11. Azenha, E. G.; Serra, A. C.; Pineiro, M.; Pereira, M. M.; de Melo, J. S.; Arnaut, L. G.; Formosinho, S. J.; Gonsalves, A. M. d'A. R. Chem. Phys. 2002, 280, 177-190.

12. Dabrowski, J. M.; Pereira, M. M.; Arnaut, L. G.; Monteiro, C. J. P.; Peixoto, A. F.; Karocki, A.; Urbanska, K.; Stochel, G. Photochem. Photobiol. 2007, 83, 897-903.

13. Osterloh, J.; Vicente, M. G. H. J. Porphyrins Phthalocyanines 2002, 6, 305-324.

14. Sharman, W. M.; van Lier, J. E.; Allen, C. M. Adv. Drug. Deliv. Rev. 2004, 56, 53-76.

15. Sasnouski, S.; Zorin, V.; Khludeyev, I.; d'Hallewin, M.; Guillemin, F.; Bezdetnaya, L. Biochim. Biophys. Acta 2005, 1725, 394-402.

16. Bonneau, S.; Vever-Bizet, C.; Morlière, P.; Mazière, J. C.; Brault, D. Biophys. J. 2002, 83, 3470-3481.

17. Pereira M. M.; Arnaut L. G.; Formosinho S. J.; Monteiro C. J. P. WO Patent 053707, 2006.

18. Lindsey, J. S.; Hsu, H. C.; Schreimen, I. C. Tetrahedron Lett. 1986, 27, 4969-4970. 19. Wagner, R. W.; Lawrence, D. S.; Lindsey, J. S. Tetrahedron Lett. 1987, 28, 3069-3070.

20. Lindsey, J. S.; Schreiman, I. C.; Hsu, H. C.; Kearney, P. C.; Marguerettaz, A. M. J. Org. Chem. 1987, 52, 827-836.

21. Gonsalves, A. M. d'A. R.; Varejao, J. M. T. B.; Pereira, M. M. J. Heterocycl. Chem. 1991, 28, 635-640.

22. Johnstone, R. A. W.; Nunes, M. L. P. G.; Pereira, M. M.; Gonsalves, A. M. d'A. R.; Serra, A. C. Heterocycles 1996, 43, 1423-1437.

23. Mahammed, A.; Goldberg, I.; Gross, Z. Org. Lett. 2001, 3, 3443-3446.

24. Saltsman, I.; Mahammed, A.; Goldberg, I.; Tkachenko, E.; Botoshansky, M.; Gross, Z. J. Am. Chem. Soc. 2002, 124, 7411-7420.

25. Gonsalves, A. M. d'A. R.; Johnstone, R. A. W.; Pereira, M. M.; de Santana, A. M. P.; Serra, A. C.; Sobral, A. J. F. N.; Stokes, P. A. Heterocycles 1996, 43, 829-838.

26. Monteiro, C. J. P.; Serpa, C.; Pereira, M. M.; Azenha, M. E.; Burrows, H. D.; Arnaut, L. G.; Tapia, M. J.; Sarakha, M.; Navaratnam, S. Photochem. Photobiol. Sci. 2005, 4, 617-624.

27. Sobral, A. J. F. N.; Eleouet, S.; Rousset, N.; Gonsalves, A. M. d'A. R.; Le Meur, O.; Bourre, L.; Patrice, T. J. Porphyrins Phthalocyanines 2002, 6, 456-462.

28. Ressurreição, A. S. M.; Pineiro, M.; Arnaut, L. G.; Gonsalves, A. M. d'A. R. J. Porphyrins Phthalocyanines 2007, 11, 50-57.

29. Banfi, S.; Cavalieri, C.; Cavazzini, M.; Trebicka, A. J. Mol. Catal. A 2000, 151, 17-28. 30. Serra, A. C.; Docal, C.; Gonsalves, A. M. d'A. R. J. Mol. Catal. A 2005, 238, 192-198

31. Mahammed, A.; Gross, Z. J. Am. Chem. Soc. 2005, 127, 2883-2887.

32. Mahammed, A.; Gross, Z. Angew. Chem., Int. Ed. 2006, 45, 6544-6547.

33. Agadjanian, H.; Weaver, J. J.; Mahammed, A.; Rentsendorj, A.; Bass, S.; Kim, J.; Dmochowski, I. J.; Margalit, R.; Gray, H. B.; Gross, Z.; Medina-Kauwe, L. K. Pharm. Res. 2006, 23, 367-377.

34. Haber, A.; Agadjanian, H.; Medina-Kauwe, L. K.; Gross, Z. J. Inorg. Biochem. 2008 102, 446-457.

35. Walker, D.; Chappel, S.; Brunschwig, B. S.; Winkler, J. R.; Gray, H. B.; Zaban, A.; Gross, Z. J. Porphyrins Phthalocyanines 2006, 10, 1259-1262.

36. Lidgard, R.; Duncan, M. W. Rapid Commun. Mass Spectrom. 1995, 9, 128-132.

37. Wyatt, M. F.; Stein, B. K.; Brenton, A. G. Anal. Chem. 2006, 78, 199-206.

38. Collander, R. Acta Chem. Scand. 1951, 5, 774-780.

39. Leo, A.; Hansch, C.; Elkins, D. Chem. Rev. 1971, 71, 525-616.

40. Kessel, D.; Smith, K. M.; Pandey, R. K. Photochem. Photobiol. 1993, 58, 200-203.

41. Grancho, J. C. P.; Pereira, M. M.; Miguel, M. G.; Gonsalves, A. M. d'A. R.; Burrows, H. D. Photochem. Photobiol. 2002, 75, 249-256.

42. Pandey, S. K.; Gryshuk, A. L.; Graham, A.; Ohkubo, K.; Fukuzumi, S.; Dobhal, M. P.; Zheng, G.; Ou, Z.; Zhan, R.; Kadish, K. M.; Oseroff, A.; Ramaprasad, S.; Pandey, R. K. Tetrahedron 2003, 59, 10059-10073.

43. Berg, K.; Selbo, P. K.; Weyer, A.; Dietze, A.; Prasmickaite, L.; Bonsted, A.; Engesaeter, B. Ø.; Angell-Petersen, E.; Warloe, T.; Frandsen, N.; Høgset, A. J. Microsc. 2005, 218, 133-147.

44. Burrows, H. D.; Pereira, M. M. Química-Síntese e Estrutura; Escolar Editora: Lisbon, 2006; Chapter 2, pp 19-23. 